\title{
MORPHOLOGICAL PARAMETERS OF PIGLETS' BLOOD IN COMBINED TREATMENT OF DYSPEPSIA
}

\author{
Key words: pig breeding; piglets; blood; diarrhea; treatment.
}

\section{Authors' personal details}

1. Zuleikha Ilyasova, Candidate of Biological Sciences, Associate Professor, Associate Professor of the Department of Infectious Diseases, Animal Hygiene and Veterinary Sanitary Inspection, Federal State Budgetary Educational Institution of Higher Education «Bashkir State Agrarian University», 450001, Ufa, 50-letiya Oktyabrya St., 34, e-mail: Zuleicha@yandex.ru.

2. Ramzia Mannapova, Doctor of Biological Sciences, Professor, Professor of the Department of Microbiology and Immunology, Russian State Agrarian University - Timiryazev Moscow Agricultural Academy, e-mail: ram.mannapova55@mail.ru.

Both Russia and other countries have developed and widely used various therapies to treat and prevent gastrointestinal disorders in young farm animals. However, not all of the therapies have high curative and economic efficiency and demonstrate some drawbacks. In this regard, the authors decided to study the combined treatment of suckling pigs' dyspepsia on blood morphological parameters and therapeutic effectiveness. The study aimed to provide scientific justification and establish an effective method for treating dyspepsia in suckling pigs and demonstrate the therapeutic effect on blood morphological parameters. The production-based experiment used 30 newborn piglets of 5 days of age. They were divided into three groups of 10 heads each. The analysis showed that Enroflon $5 \%$ injection solution combined with vitamin Eleovit

(c) Ильясова 3.3., Маннапова Р.Т. against the background of the iron-containing drug Ursoferran produced a slight increase in red blood cells and hemoglobin. Combined application of Oxytetracycline 100, Eleovit, and $5 \%$ aqueous glucose solution and Lactobacterin against the background of the iron-containing drug Ursoferran resulted in a higher content of red blood cells and hemoglobin. The authors conclude that the treatment of dyspepsia with Enroflon $5 \%$ injection solution combined with vitamin Eleovit against the background of the iron-containing drug Ursoferran is an adequate treatment for restoring the body's protective factors. Oxytetracycline 100, Eleovit, and $5 \%$ aqueous glucose solution combined with Lactobacterin against the background of the iron-containing drug Ursoferran is the most effective in controlling the inflammatory process in piglets.

УДК 636.082

DOI: $10.31563 / 1684-7628-2020-56-4-91-96$

Е.А. Никонова

\section{ВЛИЯНИЕ ПОГЛОТИТЕЛЬНОГО СКРЕЩИВАНИЯ НА УБОЙНЫЕ ПОКАЗАТЕЛИ БЫЧКОВ, ТЕЛОК И БЫЧКОВ-КАСТРАТОВ}

Ключевые слова: скотоводство; скрещивание; казахская белоголовая порода; герефорд уральского типа; бычки; телки; бычки-кастраты; убойные показатели.

Введение. Известно, что в большинстве регионов страны развитие мясного скотоводства осуществляется за счет разведения скота казахской белоголовой породы. Животные этой породы характеризуются комплексом хозяйственно-полезных качеств. В первую очередь, это неприхотливость к условиям содержания, выносливость, высокая оплата корма приростом живой массы как при пастбищном нагуле, так и при стойловом откорме. Это объясняет высокую эффективность производства мяса - говядины высокого качества и биологической полноценности [1-6].

Высокий уровень мясной продуктивности молодняка является одним из основных условий эффективного развития специализируемого мясного скотоводства. В связи с этим необходим выбор и рациональное использование породных ресурсов в отрасли. В качестве перспективы возможно использовать помесных животных [7-11]. 
Помесный молодняк вследствие обогащенной наследственности при сочетании генотипов исходных пород отличается потенциальными возможностями увеличения производимой продукции [12-15].

Цель и задачи исследования. Цель исследования - изучение влияния поглотительного скрещивания на убойные показатели молодняка разного пола. В связи с этим основной задачей являлось определение уровня мясной продуктивности молодняка при убое в 18 мес.

Условия, материалы и методы исследования. Научно-хозяйственный опыт проведен в ООО «Заилечье» Оренбургской области в 20182019 гг. В качестве объектов исследования были выбраны чистопородные и помесные бычки, телки, бычки-кастраты следующих генотипов: I - казахская белоголовая, II - 1/2 герефорд $\times 1 / 2$ казахская белоголовая, III - 3/4 герефорд $\times 1 / 4$ казахская белоголовая. При проведении исследования условия содержания и кормления молодняка всех подопытных групп были идентичны. Для определения убойных качеств по методике ВАСХНИЛ был проведен контрольный убой по 3 головы из каждой группы в возрасте $18 \mathrm{мес.}$

Результаты исследования. Известно, что линейные размеры туши оказывают определенное влияние и на мясные качества. Поэтому изучение линейных показателей туши молодняка при комплексной оценке уровня мясной продуктивности позволит дать более объективную её характеристику (таблица 1).

Таблица 1 Промеры и коэффициенты туши подопытного молодняка в возрасте 18 мес

\begin{tabular}{|c|c|c|c|c|c|c|c|c|c|c|c|c|}
\hline \multirow{3}{*}{ Группа } & \multicolumn{12}{|c|}{ Показатель } \\
\hline & \multicolumn{2}{|c|}{$\begin{array}{c}\text { длина } \\
\text { туловища, см }\end{array}$} & \multicolumn{2}{|c|}{$\begin{array}{c}\text { длина } \\
\text { бедра, см }\end{array}$} & \multicolumn{2}{|c|}{$\begin{array}{c}\text { длина } \\
\text { туши, см }\end{array}$} & \multicolumn{2}{|c|}{$\begin{array}{c}\text { обхват } \\
\text { бедра, см }\end{array}$} & \multicolumn{2}{|c|}{$\begin{array}{c}\text { Коэффициент } \\
\text { полномясности } \\
\text { туши }\left(\mathrm{K}_{1}\right), \%\end{array}$} & \multicolumn{2}{|c|}{$\begin{array}{c}\text { Коэффициент } \\
\text { выполненности } \\
\text { бедра }\left(\kappa_{2}\right), \%\end{array}$} \\
\hline & $\mathrm{X} \pm \mathrm{Sx}$ & $\mathrm{Cv}, \%$ & $\pm \mathrm{Sx}$ & $\mathrm{Cv}, \%$ & $\mathrm{X} \pm \mathrm{Sx}$ & $\begin{array}{c}\mathrm{Cv}, \\
\%\end{array}$ & $X \pm$ & $\begin{array}{c}\mathrm{Cv} \\
\%\end{array}$ & $\mathrm{X} \pm \mathrm{Sx}$ & $\mathrm{Cv}, \%$ & $\mathrm{X} \pm \mathrm{Sx}$ & $\mathrm{Cv}$ \\
\hline \multicolumn{13}{|c|}{ Бычки } \\
\hline I & 4,2 & 2,88 &, 8 & 1,43 & 198,0 & 3,42 & 98,9 & 1,48 & 0,4 & 2,48 & 37, & 3,22 \\
\hline II & $6,8=$ & 2,84 & 9 & 1,48 & $202,7 \pm$ & 3,98 & 100, & 2,84 & 3,2 & 2,8 & 39,9 & 3,48 \\
\hline III & $128,0 \pm 3,44$ & 2,89 & $76,4 \pm 1,48$ & 1,48 & $204,4 \pm 3,49$ & 3,48 & 101, & 2,28 & 14,9 & 2,80 & 140,4 & 2,94 \\
\hline \multicolumn{13}{|c|}{ Телки } \\
\hline I & $0,8 \pm 2,49$ & 2,39 & $72,7 \pm 0,94$ & 1,58 & 19 & 3,10 & 94, & 1,82 & 108,9 & 3,02 & 136, & 3,21 \\
\hline II & $126,4 \pm 2,61$ & 2,66 & $75,1 \pm 1,66$ & 1,74 & $201,5 \pm 2,62$ & 3,31 & 97, & 1,90 & 114,0 & 3,14 & 140,2 & 3,48 \\
\hline III & $127,6 \pm 2,77$ & 2,74 & $76,2 \pm 1,70$ & 1,88 & $203,8 \pm 2,71$ & 3,42 & $98,8 \pm 1,70$ & 1,99 & $116,1=$ & 3,28 & 141,4 & 3,54 \\
\hline \multicolumn{13}{|c|}{ Бычки-кастраты } \\
\hline I & 3,81 & 3,10 & 72,0 & 1,81 & $192,8 \pm 3,74$ & 3,82 & $969 \pm$ & 1,96 & 108,8 & 2,18 & 136,3 & 3,22 \\
\hline II & $125,3 \pm 3,99$ & 3,42 & $74,2 \pm 1,30$ & 1,98 & $199,4 \pm 3,80$ & 3,96 & $99,7 \pm$ & 2,10 & 112,9 & 2,20 & $138, \mathrm{C}$ & 3,41 \\
\hline III & $126,3 \pm 4,01$ & 3,84 & $75,4 \pm 2,01$ & 2,14 & $202,3 \pm 3,81$ & 3,88 & $100,2 \pm 1,72$ & 2,12 & $113,8 \pm 2,46$ & 2,30 & $139,9 \pm 3,94$ & 3,52 \\
\hline
\end{tabular}

Полученные результаты оценивают положительно влияние скрещивания исходных пород на морфометрические показатели туши подопытного молодняка. Это обусловило преимущество помесных животных II и III групп над молодняком I (контрольной) группы по величине всех изучаемых показателей. Установлено, что чистопородные бычки I группы уступали помесным сверстникам II опытной группы и помесям II поколения III опытной группы по длине туловища на 2,6 см $(2,1 \%, \mathrm{P}<0,05)$ и $3,8 \mathrm{~cm}$ $(3,1 \%$, P $<0,05)$, телки - на 5,6 см (4,6\%, $\mathrm{P}<0,01)$ и 6,8 см $(5,6 \%, \mathrm{P}<0,01)$, длине бедра на 2,1 см $(2,8 \%, \mathrm{P}<0,05)$ и 2,6 $(3,5 \%, \mathrm{P}<0,05)$, на 2,4 см $(3,3 \%, \mathrm{P}<0,05)$ и 3,5 см $(4,8 \%, \mathrm{P}<$ $0,01)$, длине туши - на 4,7 см $(2,4 \%, \mathrm{P}<0,05)$ и 6,4 см $(3,2 \%, \mathrm{P}<0,05)$, на 8,0 см $(4,1 \%, \mathrm{P}<0,01)$ и 10,3 см $(5,3 \%, \mathrm{P}<0,01)$, обхвату бедра - на 1,9 см $(1,9, \mathrm{P}>0,05)$ и $2,5 \mathrm{~cm}(2,5 \%, \mathrm{P}<0,05)$, на 2,6 см $(2,7 \%$, Р < 0,05) и 4,2 см $(4,4 \%, \mathrm{P}<0,01)$ соответственно.

Преимущество помесей I поколения II опытной группы и помесей II поколения III опытной группы было установлено и по бычкам-кастра- там. Оно составляло по длине туловища соответственно 4,5 см $(3,7 \%, \mathrm{P}<0,05)$ и $6,1 \mathrm{~cm}$ $(5,0 \%, \mathrm{P}<0,01)$, длине бедра $-2,1$ см $(2,9 \%$, $\mathrm{P}<0,05)$ и 3,4 см $(4,7 \%, \mathrm{P}<0,05)$. Преимущество помесных животных II и III групп над сверстниками I группы по длине туловища и бедра обусловлено их превосходством по длине туши, которое составляло 6,6 см $(3,4 \%, \mathrm{P}<0,01)$ и 9,5 см $(4,9 \%$, Р $<0,01)$.

Установлено, что в связи с более высоким генетическим потенциалом продуктивности помеси казахского белоголового с герефордами уральского типа II поколения III опытной группы по всем морфометрическим показателям туши превосходили помесей I поколения II опытной группы.

Так преимущество помесных бычков III опытной группы над помесными сверстниками II опытной группы по длине туловища составляло 1,2 см $(0,9 \%, \mathrm{P}>0,05)$, длине бедра $-0,5 \mathrm{~cm}$ $(0,7 \%, \mathrm{P}>0,05)$, длине туши $-1,7 \mathrm{~cm}(0,8 \%$, $\mathrm{P}>0,05)$, обхвату бедра - 0,6 см $(0,6 \%, \mathrm{P}>0,05)$, по телкам преимущество составляло по длине туловища 1,2 см $(0,9 \%, \mathrm{P}>0,05)$, длине бедра $-1,1$ 
$(1,5 \%, \mathrm{P}>0,05)$, длине туши - 2,3 см $(1,1 \%$, $\mathrm{P}<0,05)$, обхвату бедра $-1,6 \mathrm{~cm}(1,6 \%, \mathrm{P}>0,05)$, по бычкам-кастратам по длине туловища $-1,6 \mathrm{~cm}$ $(1,3 \%)$, длине бедра - 1,3 см (1,8 \%), длине туши $-2,9$ см (1,5\%), обхвату бедра - 0,5 см (0,5\%).

Известно, что достаточно информативными при характеристике мясности туши убойных животных являются коэффициент её полномясности $\left(K_{1}\right)$ и коэффициент выполненности бедра $\left(K_{2}\right)$.

Установлено преимущество помесей по величине изучаемых показателей. Так бычки казахской белоголовой породы I (контрольной) группы уступали сверстникам II и III опытных групп по величине коэффициента полномясности туши $\left(\mathrm{K}_{1}\right)$ соответственно на $2,8 \%(\mathrm{P}<0,05)$ и $4,5 \%(\mathrm{P}<0,05)$, а по уровню коэффициента выполненности бедра преимущество помесей составляло $2,0 \%(\mathrm{P}<0,05)$ и $2,5 \%(\mathrm{P}<0,05)$. По группе телок преимущество телок составляло по величине коэффициента полномясности туши $(\mathrm{K} 1)-5,1 \%(\mathrm{P}<0,01)$ и 7,2 $(\mathrm{P}<0,01)$, коэффициенту выполненности бедра $-3,4 \%(\mathrm{P}<0,05)$ и 4,6\% $(\mathrm{P}<0,01)$, по бычкам-кастратам соответственно 4,1 \% $(\mathrm{P}<0,05)$ и $5,0 \%(\mathrm{P}<0,05), 2,6 \%$ $(\mathrm{P}<0,05)$ и $3,6 \%(\mathrm{P}<0,05)$.

При этом помесные животные III опытной группы превосходили помесных сверстников II опытной группы по величине коэффициента полномясности туши по бычкам на $1,7 \%$ $(\mathrm{P}>0,05)$, телкам - на 2,1 \% (P > 0,05), бычкамкастратам - 0,9\% $(\mathrm{P}>0,05)$, по уровню коэффициента выполненности бедра соответственно на $0,5 \%(\mathrm{P}>0,05), 1,2 \%(\mathrm{P}>0,05), 1,0 \%(\mathrm{P}>0,05)$.

В целом, судя по данным, изложенным в таблице 19, молодняк всех генотипов характеризовался хорошо выраженными мясными качествами при явном преимуществе помесей.

Эта закономерность подтверждается и материалами, характеризующими убойные качества молодняка разных генотипов.

При этом бычки I контрольной группы (чистопородные казахской белоголовой породы) уступали помесям II и III опытной группы по предубойной живой массе соответственно на 25,0 кг $(5,3 \%, \mathrm{P}<0,01)$ и 27,2 кг $(5,8 \%, \mathrm{P}<0,01)$, телки - на 37,3 кг $(10,9 \%, \mathrm{P}<0,001)$ и 40,8 кг $(11,9 \%, \mathrm{P}<0,001)$, бычки-кастраты - на 24,2 кг $(5,5 \%, \mathrm{P}<0,05)$ и 39,6 кг $(9,0 \%, \mathrm{P}<0,001)$.

В связи с различной предубойной живой массой отмечался неодинаковый уровень массы парной туши у молодняка разного генотипа. При этом достоверное преимущество по величине анализируемого показателя имели помесные животные.

Установлено, что помесные бычки II и III опытных групп превосходили чистопородных сверстников I (контрольной) группы по абсолютной массе парной туши соответственно на 19,9 кг
$(7,6 \%, \mathrm{P}<0,01)$ и 22,3 кг $(8,5 \%, \mathrm{P}<0,01)$, а её выходу - на $1,1 \%$ и 1,3 \%, по телкам - на 28,1 кг $(14,0 \%, \mathrm{P}<0,01)$ и 30,5 кг $(15,9 \%, \mathrm{P}<0,001)$, $1,9 \%$ и 2,0 \%, по бычкам-кастратам - 19,0 кг $(7,8 \%, \mathrm{P}<0,01)$ и 29,2 кг $(11,9 \%, \mathrm{P}<0,001)$, относительной массе (выходу туши) - на $1,2 \%$ и $1,5 \%$.

Помесный молодняк II и III опытных групп уступал им по абсолютной массе внутреннего жира-сырца соответственно на 2,2 кг (36,8 \%, Р < $0,05)$ и 2,0 кг $(29,0 \%, \mathrm{P}<0,05)$, относительной на $0,8 \%$ и $0,5 \%$.

В то же время по убойной массе наблюдалось преимущество помесей II и III опытных групп по всем группам. Достаточно отметить, что бычки I (контрольной) группы уступали помесям по величине изучаемого показателя на 20,3 кг $(7,5 \%, \mathrm{P}<0,01)$ и $22,1(8,2 \%, \mathrm{P}<0,01)$, телки - на 25,9 кг $(12,9 \%, \mathrm{P}<0,001)$ и 29,5 кг $(14,7 \%, \mathrm{P}<0,001)$, бычки-кастраты - на 18,6 кг $(7,3 \%, \mathrm{P}<0,001)$ и 29,1 кг $(11,4 \%, \mathrm{P}<0,001)$ соответственно. Аналогичная закономерность наблюдалась и по убойному выходу. При этом помесные животные казахской белоголовой породы с герефордами уральского типа пород первого и второго поколения превосходили чистопородный молодняк казахской белоголовой породы I (контрольной) группы по величине убойного выхода по бычкам - на 1,2 \% и 1,3 \%, по телкам - на $1,1 \%$ и $1,5 \%$, бычкам-кастратам $1,0 \%$ и $1,3 \%$ соответственно.

Характерно, что изучаемый вид скрещивания казахского белоголового скота с герефордами отражался повышением уровня мясной продуктивности, вследствие чего помеси второго поколения III опытной группы во всех случаях превосходили по убойным качествам помесей I поколения II опытной группы. Так это преимущество помесных бычков III опытной группы над помесями II опытной группы по предубойной живой массе составляло 2,2 кг $(0,4 \%, \mathrm{P}>0,05)$, абсолютной массе парной туши $-2,4$ кг $(0,8 \%, \mathrm{P}<0,05)$, относительной её массе $-0,2 \%$, убойной массе $-1,8$ кг $(0,6 \%, \mathrm{P}>0,05)$ и убойному выходу $-0,1 \%$.

По телкам преимущество помесей II поколения по герефордам над полукровными сверстницами II опытной группы составляло по предубойной живой массе 3,5 кг $(0,9 \%, \mathrm{P}<0,05)$, по абсолютной и относительной массе парной туши - 2,4 кг $(1,1 \%, \mathrm{P}>0,05)$ и $0,1 \%$, по убойной массе $-3,6$ кг $(1,6 \%, \mathrm{P}<0,05)$ и убойному выходу $-0,4 \%$.

Аналогичные результаты получены и по бычкам-кастратам. Так помеси II группы уступали помесям III опытной группы по предубойной живой массе - на 15,4 кг $(3,3 \%, \mathrm{P}<0,05)$, по абсолютной массе парной туши на 10,2 кг 
$(3,9 \%, \mathrm{P}<0,05)$ относительной её массе (выходу) - на $0,3 \%$, убойной массе - на 10,5 кг $(3,8 \%, \mathrm{P}<0,05)$, убойному выходу - на $0,03 \%$.

При межгрупповых различиях по генотипу было также установлено изменение значения изучаемых показателей в зависимости от пола животных. Так чистопородные бычки превосходили чистопородных телок и бычков-кастратов по предубойной массе на 127,8 кг $(37,2 \%, \mathrm{P}<$ $0,001)$ и 29,6 кг $(6,8 \%, \mathrm{P}<0,01)$, массе парной туши - на 70,6 кг $(36,7 \%, \mathrm{P}<0,001)$ и 17,8 кг $(7,3 \%, \mathrm{P}<0,01)$. При этом телки уступали бычкам-кастратам по величине изучаемых показателей соответственно на 43,0 кг $(12,6 \%, \mathrm{P}<0,001)$ и 52,5 кг $(27,5 \%, \mathrm{P}<0,001)$.

Характерно, что по выходу туши межгрупповых достоверных различий не установлено. Наибольшее содержание внутреннего жирасырца было установлено у бычков-кастратов, они превосходили бычков по этому показателю на 2,6 кг $(32,5 \%, \mathrm{P}<0,05)$, телок - на 2,7 кг $(34,2 \%, \mathrm{P}<0,05$,$) . Соответственно бычки-ка-$ страты превосходили сверстников по выходу внутреннего жира-сырца на $0,8-0,1 \%$. При этом бычки характеризовались наибольшей убойной массой. Они превосходили телок и бычков-кастратов по этому показателю на 70,7 кг (35,3\%, $\mathrm{P}<0,001)$ и 15,8 кг $(6,2 \%, \mathrm{P}<0,01)$, но уступали по убойному выходу телкам на 0,8 \%, бычкамкастратам - на $0,4 \%$.

Аналогичные результаты были получены по помесям. Так бычки I поколения превосходили телок и бычков-кастратов этого же генотипа по предубойной живой массе на 115,5 кг (30,4\%, $\mathrm{P}<0,001)$ и 30,4 кг $(6,5 \%, \mathrm{P}<0,01)$, массе парной туши - на 62,4 кг $(28,3 \%, \mathrm{P}<0,001)$ и 18,7 кг $(7,1 \%, \mathrm{P}<0,01)$, убойной массе - на 65,1 кг $(28,8 \%$, Р $<0,001)$ и 16,9 кг $(6,2 \%, \mathrm{P}<0,05)$. При этом телки уступали бычкам-кастратам по анализируемым показателям соответственно на 85,1 кг $(22,4 \%, \mathrm{P}<0,001), 43,7$ кг $(19,8 \%$,
$\mathrm{P}<0,001), 48,2$ кг $(21,3 \%, \mathrm{P}<0,001)$. Наибольшее отложение внутреннего жира-сырца отмечалось у бычков-кастратов. Они превосходили бычков по массе внутреннего жира-сырца и его выходу на 1,8 кг и 0,5 \%, телок - на 4,5 кг и $0,7 \%$. Наибольшим выходом парной туши и убойным выходом характеризовались телки. Так они превосходили по этим показателям бычков на $0,9 \%$ и $0,7 \%$, бычков-кастратов - на $1,2 \%$ и $0,5 \%$ соответственно. Помеси второго поколения отличались сходными межгрупповыми различиями. Чистопородные телки уступали бычкам и бычкам-кастратам второго поколения по предубойной живой массе на 114,2 кг $(29,7 \%, \mathrm{P}<0,001)$ и 97 кг $(25,3 \%, \mathrm{P}<0,001)$, мacce парной туши - на 62,4 кг $(28,0 \%$, $\mathrm{P}<0,001)$ и 51,5 кг $(23,1 \%, \mathrm{P}<0,001)$, масcе внутреннего жира-сырца - на 0,9 кг $(13,8 \%$, $\mathrm{P}<0,05)$ и 3,6 кг $(52,2 \%, \mathrm{P}<0,05)$, убойной масcе - на 63,3 кг $(27,6 \%, \mathrm{P}<0,001)$ и 55,1 кг $(24,0 \%, \mathrm{P}<0,01)$. При этом бычки превосходили бычков-кастратов по предубойной живой массе на 17,2 кг $(3,6 \%, \mathrm{P}<0,01)$, массе парной туши на 10,9 кг $(4,0 \%, \mathrm{P}<0,05)$, убойной массе - на 8,2 кг $(2,9 \%, \mathrm{P}<0,05)$, но уступали им по массе внутреннего жира-сырца на 2,7 кг (34,6 \%, $\mathrm{P}>0,05)$. Характерно, что наибольшим выходом парной туши и убойным выходом характеризовались телки. Они превосходили бычков по этим показателям соответственно на $0,8 \%$ и $1,0 \%$, бычков-кастратов - на $1,0 \%$ и $0,6 \%$.

Вывод. Полученные и проанализированные данные свидетельствуют о высоком уровне убойных качеств как чистопородного, так и помесного молодняка. При этом по всем показателям, характеризующим мясность животных, помеси отличались наибольшими показателями при лидирующем положении помесей казахской белоголовой и герефордской пород второго поколения по герефордам (3/4 герефорд $\times 1 / 4$ казахская белоголовая) III опытной группы.

\section{Библиографический список}

1. Бозымов, К.К. Технология производства продуктов животноводства [Текст] / К.К. Бозымов, Е.Г. Насамбаев, В.И. Косилов, К.Г. Есенгалиев, А.Б. Ахматалиева, А.К. Султанова // Уральск. Западно-Казахстанский аграрно-технический университет. 2016. Т. 1. 399 с.

2. Заднепрянский, И.П. Особенности роста и развития бычков мясных, комбинированных пород и помесей [Текст] / И.П. Заднепрянский, В.И. Косилов, С.С. Жаймышева, В.А Швынденков // Известия Оренбургского государственного аграрного университета. 2012. № 6 (38). C. 105-107.
3. Никонова, Е.А. Репродуктивная функция маточного поголовья при создании помесных мясных стад телок [Текст] / Е.А. Никонова, В.И. Косилов, К.К. Бозымов, Н.М. Губашев // Вестник мясного скотоводства. 2014. № 2 (85). C. $49-57$.

4. Косилов, В.И. Мясные качества чернопестрого и симментальского скота разных генотипов [Текст] / В.И. Косилов, Г.Л. Заикин, Э.Ф. Муфазалов, С.И. Мироненко. Оренбург, 2006. $196 \mathrm{c}$.

5. Инновационные технологии в скотоводстве [Текст] / Д.С. Вильвер, О.А. Быкова, 
В.И. Косилов, Е.А. Никонова, Т.С. Кубатбеков, С.С. Жаймышева. Челябинск, 2017. 196 с.

6. Потребление и использование питательных веществ рационов бычками симментальской породы при включении в рацион пробиотиотической добавки Биогумитель 2 г [Текст] / В.И. Косилов, Е.А. Никонова, Н.В. Пекина, Т.С. Кубатбеков, Д.С. Вильвер, Т.А. Иргашев // Известия Оренбургского государственного аграрного университета. 2017. № 1 (63). С. 204 206.

7. Губайдуллин, Н.М. Комплексная оценка мясной продуктивности бычков чёрно-пёстрой породы и её помесей с абердин-ангусами и лимузинами [Текст] / Н.М. Губайдуллин, Р.С. Исхаков // Известия Оренбургского государственного аграрного университета. 2011. № 3 (31). C. $163-166$.

8. Косилов, В.И Эффективность двух-трехпородного скрещивания скота [Текст] / В.И. Косилов, С.И. Мироненко // Молочное и мясное скотоводство. 2005. № 1. С. 11-12.

9. Косилов, В.И. Весовой рост бычков симментальской породы и её двух-трехпородных помесей с производителями голштинской, немецкой пятнистой и лимузинской пород [Текст] / В.И. Косилов, С.И. Мироненко, Е.А. Никонова // Вестник мясного скотоводства. 2012. № 2 (76). C. 44-49.

10. Мясная продуктивность молодняка черно-пестрой породы и ее помесей с лимузинами [Текст] / Р.С. Исхаков, Н.М. Губайдуллин, X.X. Тагиров // Молочное и мясное скотоводство. 2014. № 4. С. 8-10.
11. Mironova I.V., Kosilov V.I., Nigmatyanov A.A., Saifullin R.R., Senchenko O.V., Chalirachmanov E.R., Chernenkov E.N. Nutrient and energy digestibility in cows fed the energy supplement «felucen». Research Journal of Pharmaceutical, Biological and Chemical Sciences. 2018. Vol. 9. No 6. P. 18-25.

12. Sedykh T.A., Gizatullin R.S., Kosilov V.I., Chudov I.V., Andreeva A.V., Giniyatullin M.G., Islamova S.G., Tagirov Kh.Kh., Kalashnikova L.A. Adapting australian hereford cattle to the conditions of the Southern Urals. Research Journal of Pharmaceutical, Biological and Chemical Sciences. 2018. Vol. 9. No 3. P. 885-898.

13. Tyulebaev S.D., Kadysheva M.D., Litovchenko V.G., Kosilov V.I., Gabidulin V.M. The use single-nucleotide polymophism in creating a crossline of meat Simmentals. Conference on innovations in Agricultural and Rural development: IOP Conf. Series: Earth and Environmental Science. 2019. № 341.

14. Kayumov F.G., Kosilov V.I., Gerasimov N.P., Bykova O.A. The effect of snp polymorphisms in growth hormone gene on weight and linear growth in cros-sbred red angus $\times$ kalmyk heifers. Digital agriculture - development strategy. Proceedings of the International Scientific and Practical Conference (ISPC 2019). Advances in Intelligent Systems Research. 2019. P. 325-328.

15. Fatkullin R.R., Ermolova E.M., Kosilov V.I., Matrosova Yu.V., Chulichkova S.A. Biochemical Status of Animal Organism Under Conditions of Technogenic Agroecosystem. J. Advances in Engineering Research. 2018. Vol. 151. P. 182-186.

\section{Сведения об авторе}

Никонова Елена Анатольевна, кандидат сельскохозяйственных наук, доцент кафедры технологии производства и переработки продукции животноводства, ФГБОУ ВО Оренбургский ГАУ, 460014, г. Оренбург, ул. Челюскинцев, 18, e-mail: nikonovaea84@mail.ru.

В статье приводятся результаты оценки убойных качеств чистопородных и помесных бычков, телок, бычков-кастратов, полученных от поглотительного скрещивания казахской белоголовой породы с уральским герефордом. Установлено, что помеси превосходили чистопородных животных по всем показателям. Достаточно отметить, что при убое в 18 мес чистопородные бычки уступали помесям II и III опытных групп по массе парной туши на 19,9 кг $(7,6 \%, \mathrm{P}<0,01)$ и 22,3 кг $(8,5 \%, \mathrm{P}<0,01)$, а её выходу - на $1,1 \%$ и $1,3 \%$, по убойной массе на 20,3 кг $(7,5 \%, \mathrm{P}<0,01)$ и $22,1(8,2 \%, \mathrm{P}<0,01)$, по убойному выходу на $1,2 \%$ и $1,3 \%$. Помесные телки II и III опытных групп превосходили чистопородных сверстников I (контрольной) группы по абсолютной массе парной туши соответственно на 28,1 кг $(14,0 \%, \mathrm{P}<0,01)$ и 30,5 кг $(15,9 \%, \mathrm{P}<0,001)$, по ее выходу - на $1,9 \%$ и $2,0 \%$, по бычкам-кастратам - 19,0 кг (7,8\%, Р < $0,01)$ и 29,2 кг $(11,9 \%, \mathrm{P}<0,001), 1,2 \%$ и $1,5 \%$. При этом в связи с более высоким генетическим потенциалом продуктивности помеси казахского белоголового с герефордами уральского типа II поколения III опытной группы по всем убойным показателям превосходили помесей I поколения II опытной группы. 


\title{
E. Nikonova
}

\section{INFLUENCE OF ABSORPTION CROSSBREEDING ON SLAUGHTER INDICATORS OF CALVES, HEIFERS AND CASTRATED CALVES}

Key words: cattle breeding; crossbreeding; Kazakh white-headed breed; Hereford of the Ural type; bulls; heifers; bull-calves; slaughter indicators.

\section{Authors' personal details}

Elena Nikonova, Candidate of Agricultural Sciences, Associate Professor of the Department of Production Technology and Processing of Livestock Products, Orenburg State Agrarian University, 460014, Orenburg, Chelyuskintsev St., 18, e-mail: nikonovaea@mail.ru.

The article presents the results of evaluating the slaughter qualities of purebred and crossbred bulls, heifers, castrate bulls obtained from the absorption crossing of the Kazakh white-headed breed with the Ural Hereford. It was found that purebred animals were inferior to hybrids in all indicators. It suffices to note that the slaughter at 18 months purebred bulls were inferior to crosses of II and III experimental groups in terms of the weight of a paired carcass by $19,9 \mathrm{~kg}(7,6 \%, \mathrm{P}<0,01)$ and $22,3 \mathrm{~kg}(8,5 \%$, $\mathrm{P}<0,01)$, and yield - by $1,1 \%$ and $1,3 \%$, by slaughter weight by $20,3 \mathrm{~kg}(7,5 \%, \mathrm{P}<0,01)$ and $22,1(8,2 \%, \mathrm{P}<0,01)$, by slaughter yield by $1,2 \%$ and 1,3\%. Mixed heifers of the II and III experi-

(C) Никонова Е.A. mental groups surpassed the purebred peers of the I (control) group in the absolute weight of the paired carcass, respectively - by $28,1 \mathrm{~kg}(14,0 \%, \mathrm{P}<0,01)$ and $30,5 \mathrm{~kg}(15,9 \%, \mathrm{P}<0,001)$, by its output - by $1,9 \%$ and $2,0 \%$, by castrate bulls $-19,0 \mathrm{~kg}(7,8 \%$, $\mathrm{P}<0,01)$ and $29,2 \mathrm{~kg}(11,9 \%, \mathrm{P}<0,001), 1,2 \%$ and $1,5 \%$. At the same time, the connections with a higher genetic productivity potential of the hybrid of the Kazakh white-headed with the Herefords of the Ural type of the second generation $(3 / 4$ Hereford $\times 1 / 4$ Kazakh white-headed) of the III experimental group in all slaughter indicators exceeded the hybrids of the first generation $(1 / 2$ Hereford $\times 1 / 2 \mathrm{Ka}-$ zakh white-headed) of the II experimental group.

УДК 619:591.465.31

DOI: 10.31563/1684-7628-2020-56-4-96-106

Е.Н. Сковородин, Г.В. Базекин, А.Р. Шарипов

\section{МОРФОЛОГИЧЕСКИЕ И ГИСТОХИМИЧЕСКИЕ ОТЛИЧИЯ ЖЕЛТЫХ ТЕЛ ЯИЧНИКОВ КОРОВ ПРИ ПОЛОВОМ ЦИКЛЕ, БЕРЕМЕННОСТИ, ОВАРИАЛЬНОЙ ПАТОЛОГИИ И ПОСЛЕ ВВЕДЕНИЯ ПРОСТАГЛАНДИНА РGF2 $\alpha$}

\author{
Ключевые слова: коровы; яичники; жслтое тело; морфология; гистохимия; простагландин \\ PGF $2 \alpha$.
}

Введение. Полноценность половых циклов, возможность оплодотворения, нормальное течение беременности и эмбриональное развитие животных, даже полноценное функционирование мозга во многом обеспечивается эндогенными прогестогенами, главным образом прогестероном. Препараты на основе этого гормона являются основными при синхронизации охоты, лечении болезней яичников и матки. Считается, что прогестерон начинает вырабатываться после полового созревания в основном желтым телом яичника (ЖТ) и в небольших количествах надпочечниками, а также плацентой во время беременности $[8,14,17]$, хотя лютеиновые атретические тела описываются уже у поздних плодов [22].
Морфология и функция ЖТ и лютеиновых структур яичника крупного рогатого скота остается предметом интенсивных исследований и дискуссии $[4,12,25,27]$. В литературе, посвященной морфологической характеристике желтых тел беременности, имеются существенные противоречия. Окончательно не определен клеточный состав ЖТ. Описаны гранулезо-лютеиновые клетки крупной величины, средние и мелкие тека-лютеиновые клетки, имеющие существенные морфологические отличия [24]. Неясна функция полостных и кистозных ЖТ, а также особенности васкуляризации этой железы $[9,21]$. Не установлено функциональное значение цитоплазматических гранул лютеоцитов [5, $9,24]$. В имеющихся работах описываются раз- 